Teksty Drugie 2015, 1, s. 186-210

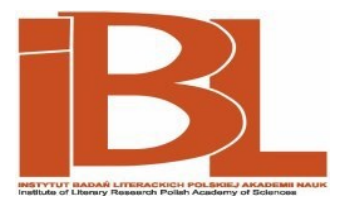

\title{
Ecological Humanities
}

Ewa Domańska 
Ewa Domańska

\title{
Ecological Humanities
}

DOI: 10.18318/td.2015.en.1.12

\author{
Ewa Domańska is \\ associate professor \\ of theory and history \\ of historiography \\ in the Department \\ of History, Adam \\ Mickiewicz University \\ in Poznan, Poland and \\ since 2002 visiting \\ associate professor at \\ the Department of \\ Anthropology, Stanford \\ University. Her \\ teaching and research \\ interests include \\ comparative theory \\ of the humanities \\ and social sciences, \\ history and theory \\ of historiography, \\ posthumanities and \\ ecological humanities. \\ She is the author and \\ editor of many books, \\ recently: Existential \\ History (in Polish, \\ 2012); History and \\ the Contemporary \\ Humanities (in \\ Ukrainian, 2012) and \\ History Today (ed. \\ with R. Stobiecki and \\ T. Wiślicz, in Polish, \\ 2014). Contact: ewa. \\ domanska@amu. \\ edu.pl
}

T his article strives to make a preliminary attempt at defining specific features of ecological humanities ${ }^{1}$ as a symptom of the emergence of a new paradigm. I am particularly interested in the trend of ecological humanities which has been developing at an accelerated rate since the late nineties in the frame of posthumanist

1 In the literature of the subject, ecological humanities is often also defined as environmental humanities or sustainable humanities understood as a domain that is actively involved in the sustainable development and future oriented conviviality (Stephanie LeMenager and Stephanie Foote, "The sustainable humanities", PMLA, vol. 127, no. 3 (May 2012): 572-578.). In this article I will be using the term ecological humanities (or ecoposthumanities), in order to distinguish it from both postmodernist movements of "deep ecology" (which I am referencing), and from "social ecology" tied to the left-wing movements and Marxism, and from technocratic understanding of environmental and sustainable research, which, according to the critics, are conserving a destructive development of the global capitalism. (See Valerie de Campos Mello, "Mainstreaming the Environment: Global Ecology, International Institutions and the Crisis of Environmental Governance", Human Ecology Review, vol. 7, no 1 (2000): 31-43.) I propose not to use the term ecological humanities as synonymous with environmental humanities as the latter is tied predominantly to various movements of environmental protection, whereas ecologism is a much broader notion and encompasses not only a specific idea of knowledge/science, its practice and the ways of cognition, but also a change in consciousness.

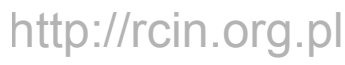


criticism of anthropocentrism², Eurocentrism (and "a predatory discourse of Western cognitive imperialism"3), while emphasizing the validity of creating a complementary and inclusive knowledge emerging from the integration of the humanities and social sciences with life sciences and with native knowledges (indigenous ways of knowing). In this sense and with the purpose of distinguishing it from the earlier approaches, this domain can be named as ecoposthumanities. Further in this article, I will present general characteristics of ecological humanities and offer a working definition of this domain. I will also outline its biohumanistic background and ties with indigenous knowledges. I will consider the hypotheses that ecological humanities co-create a future utopia, which unveils an eternal longing for belonging to community, however, in this case, not just a human community, but a multispecies metacommunity (also in the sense of fabricated species) considered in a planetary perspective of carbon based life on Earth. Using the latest discoveries of neuro- and cognitive sciences, it is also anticipating the future knowledge production in terms of extended mind and distributed cognition.

It has to be noted that the definition of mutual relations among domains/ trends/approaches/paradigms, which are defined with the use of different terms as non-anthropocentric humanities, posthumanities, ecological humanities, biohumanities, is difficult because of the fact, that all of them, it seems to me, are the harbingers of the new paradigm, which is in the process of becoming. It is therefore defined through its characteristics: it is non- or anti-anthropocentric (hence the non-anthropocentric humanities); it builds a holistic vision of combined humanities and life sciences (biohumanities), to a large extent it references ecological thinking and values (ecological humanities) and it invokes a conglomerate of various, often mutually exclusive

2 Cary Wolfe, What is Posthumanism? (Minneapolis: University of Minnesota Press, 2010); Tamar Sharon, "A Cartography of the Posthuman, Humanist, Non-Humanist and Mediated Perspectives on Emerging Biotechnologies. Krisis, no. 2 (2012): 5-19; Stefan Herbrechter, Posthumanism. A Critical Analysis (London: Bloomsbury Academic, 2013); Pramod Nayar, Posthumanism (Cambridge, UK: Polity Press, 2013).

3 The term "epistemicide" is often used to indicate predatory discourse of Western epistemology against indigenous knowledges. See: "Different Knowings and the Indigenous Humanities", Daniel Coleman in Conversation with Marie Battiste, Sákéj Henderson, Isobel M. Findlay, and Len Findlay, ECS: English Studies in Canada, vol. 38, no. 1 (2012): 142. Cf. also: J. Taboho Lebakeng, M. Manthiba Phalane and Nase Dalindjebo, "Epistemicide, Institutional Cultures and the Imperative for the Africanisation of Universities in South Africa" Alternation, vol. 13, no. 1 (2006): 70-87, Karen Bennett, "Epistemicide! The Tale of a Predatory Discourse", Translator, vol. 13, no. 2 (2007): 151-169, Cognitive /ustice in a Global World: Prudent Knowledges for a Decent Life, ed. by Boaventura de Sousa Santos (Lanham: Lexington Books, 2007). 
tendencies defined as posthumanism (posthumanities). Moreover, it is often emphasized, that it is posteuropean (with implied criticism of the imperial West; Europe is no longer the center of knowledge production), post-human (the idea of human nature is criticized; human epistemic authority of knowledge building is questioned), post-gender (the departure from sexual identification and the ability to modify the human being so as to rid it of sexual characteristics); post-white (white race is no longer the dominant race) ${ }^{4}$.

In the case of ecological humanities (concerning also the non-anthropocentric humanities and posthumanities), the focus is not only and not as much on opting for a certain research program and an interest in the avant-garde trends, but also on promoting a different vision of the world. Mainly because it is based on relational thinking ${ }^{5}$, which stresses mutual ties, codependency, co-existence and joint life of nature-culture, human, non-human beings and the environment. In this option the objective is to change consciousness and also to achieve a social transformation and to build "inclusive democracy" or/and participatory ecological democracy ${ }^{\mathbf{6}}$; the possibility of composing a "common world" comprised of humans and non-humans (Bruno Latour). In this vision the mutual world is understood not in the categories of globalization, but on one hand in a planetary and cosmic perspective, and in molecular perspective, on the other?.

Henryk Skolimowski, the founder of ecophilosophy, stated, as early as the 1970's, that physics, seen as the model of cognition, promotes the kind of

4 In this article I do not discuss the new media, virtuality and the digital technology tied to ecological humanities (e.g., the issue of artificial nature or "ecology without nature" - Timothy Morton, Ecology without Nature: Rethinking Environmental Aesthetics (Cambridge, MA: Harvard University Press 2009).

5 Obviously, relationism (privileging thinking in terms of relations) is nothing new, however during recent decades, affirming relational character of reality (visible for example in thing studies) and thinking in the terms of networks and entanglements, it gained a new meaning, different from its traditional epistemological notion. To make this distinction, some researchers use the term relationalism. See: Joseph Kaipayil, Relationalism: A Theory of Being (Bangalore: JIP Publications, 2009), 9. Charalambos Tsekeris, "Relationalism in Sociology: Theoretical and Methodological Elaborations", Facta Universitatis, Series: Philosophy, Sociology, Psychology and History, vol. 9, no. 1 (2010): 139-148.

6 Cf.: Roy Morrison, Ecological Democracy (Boston: South End Press, 1995), and also, Franz J. Broswimmer, Ecocide. A Short History of the Mass Extinction of Species (London: Pluto Press, 2002), 97ff.

7 Bruno Latour, Reassembling the Social. An Introduction to Actor-Network-Theory (Oxford: Oxford University Press, 2005), 254, 259, 262; Isabelle Stengers, Cosmopolitics, trans. by Robert Bononno (Minneapolis: University of Minnesota Press, 2010); Alan Dove, "Microbiomatics: The Germ Theory of Everything", Science, vol. 340, no. 6133 (2013): 763-765. 
understanding of rationality and objectivism which plays a role in derogating knowledge and is not conducive to the cognitive needs of humans. He also pointed out that the interests of survival of the human species dictate the need for a knowledge furthering the objective of keeping it alive. Biology, offering a different paradigm of cognition, can, in his opinion, contribute to building such knowledge ${ }^{8}$. Ecological humanities of today seems to be going in this direction and keeps returning to the evolutionary understanding of science from the perspective of adaptation to the changes occurring in the world on the one hand, and to discussion about whether science (humanities) has a survival value for the human species (and for life in general), on the other. This is one of the reasons why the paradigm shift observed in the last decade adopts different goals for the production of knowledge and different points of departure for it. Life itself (or zoë) ${ }^{9}$, in its postanthropocentric understanding (Rosi Braidotti), becomes such a point, also synthetic life and necrolife (dead matter as a habitat for living organisms) in its various forms and appearing on different levels (from life on the molecular level to macroorganisms and complex technologies), as well as researching relations, which support and enrich it. The idea of carbon based life becomes a base of co-substantive identification of earthly life forms.

Some researchers approach life affirmation critically. It has been stressed more often recently that humanists should include the law of entropy in their considerations as it contends that every insular system tends toward the state of equilibrium, but also that all systems have limited lifespans ${ }^{10}$. The extinction of the human species (just as much as of other species) is therefore a real possibility ${ }^{11}$. One of the main representatives of ecoposthumanities, Ursula K. Heise, noted, that the discourse of extinction of species is of an anthropogenic (caused by humans) nature. The story of the possibility of extinction of the human species has therefore an anthropocentric tilt ${ }^{\mathbf{2}}$.

8 Henryk Skolimowski, "Problems of rationality in biology", in: Studies in the Philosophy of Biology, ed. by Francisco Jose Ayala and Theodosius Dobzhansky (Berkeley: University of California Press, 1974), 224.

9 Rosi Braidotti, "Feminist Epistemology After Postmodernism: Critiquing Science, Technology and Globalisation". Interdisciplinary Science Reviews, vol. 32, no. 1 (2007): 71; ibid, "Locating Deleuze's Eco-Philosophy: Between Bio/Zoe Power and Necro-Politics", in: Deleuze and Law Forensic Futures, ed. by Rosi Braidotti, Claire Colebrook and Patrick Hanafin (London: Palgrave MacMillan, 2009), 96-116. Cf.: popular science book by Jeremy Rifkin, Entropy: A New World View (New York: Viking Press, 1980). Alan Weisman, The World Without Us (New York: Thomas Dunne Books; St. Martin Press, 2007). tions, vol. 18 (2010): 49-72. Cf. also: Terry Glavin, The Sixth Extinction. Journeys Among the Lost 
Within the growing interest in thinking in the categories of ecology and environmental protection in the humanities, new domains began to emerge as early as in the 1970's, such as ecological anthropology, as well as ecological history and philosophy, joined later by: ecoaesthetics ${ }^{\mathbf{1 3}}$, ecomedia and ecocinema $\mathbf{1 4}^{\mathbf{1 4}}$, ecolinguistics ${ }^{\mathbf{1 5}}$, ecopoetics ${ }^{\mathbf{1 6}}$, ecocriticism ${ }^{\mathbf{1 7}}$, ecosemiotics, political ecology, etc. Also, there has been talk about eco-domains as part of a so called green cultural studies. Some researchers regard cultural ecology ${ }^{\mathbf{1 8}}$ as a new transdisciplinary paradigm (also in literary studies). But only in the last few years, posthumanist inspirations have begun permeating these disciplines and revealing themselves through the use of such descriptions as post-human geography ${ }^{19}$.

\section{Ecological Humanities - A Preliminary Outline}

Toward the end of the 1990's, Frithof Capra stated that we are witnessing a paradigmatic turn in the sciences, from physics to the life sciences,

and Left Behind (New york: St. Martin's Press, 2007); The Anthropology of Extinction. Essays on Culture and Species Death, ed. by Genese Marie Sodikoff (Bioomington: Indiana University Press, 2012).

13 Arnold Berleant, Aesthetics Beyond the Arts. New and Recent Essays (Aldershot: Ashgate, 2012).

14 Ecocinema Theory and Practice, ed. by Stephen Rust, Salma Monani, and Sean Cubitt (Routledge, 2012); Sean Cubitt, EcoMedia (New York: Rodopi, 2005).

15 The Ecolinguistics Reader: Language, Ecology and Environment, ed. by Alwin Fill and Peter MühIhäusler (London and New York: Continuum, 2001).

16 Scott Knickerbocker, Ecopoetics: The Language of Nature, the Nature of Language (Amherst: University of Massachusetts Press, 2012).

17 Apart from classical texts by Lawrence Buell (including The Future of Environmental Criticism, (Malden, MA: Blackwell, 2005); in the new literature, it's worth pointing to: Greg Garrard, Ecocriticism (Oxon and New York: Routledge, 2012), Configurations: A Journal of Literature, Science and Technology, vol. 18, no. 1-2 (2010) published the special issue "Ecocriticism and Biology", combining the efforts of literature scholars and biologists in uniting the two cultures. The authors call for greater focus on life sciences, which can enrich ecocriticism as an interdisciplinary field researching connections between literature and human environment. A theme issue entitled "At the Intersections of Ecocriticism", was also published by Qui Parle: Critical Humanities and Social Sciences, vol. 19, no. 2 (2012).

18 Hubert Zapf(Hg.), Kulturökologie und Literatur: Beiträge zu einem transdisziplinären Paradigma der Literaturwissenschaft (Heidelberg: Winter, 2008).

19 Fiona Coyle, „Posthuman Geographies? Biotechnology, nature and the demise of the autonomous human subject", Social \& Cultural Geography, vol. 7, no. 4 (2006): 505-523 (theme issue: "Posthuman Geographies").

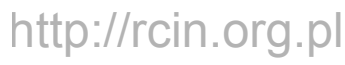


accompanied by a change in the system of values as a departure point for researchers, that is, in a broader sense, ecological thinking ${ }^{20}$. The new paradigm, defined by Capra as a holistic or ecological paradigm, is characterized, in his approach, by a number of turns: from rationality to intuition, from selfconfirmation to integration, from domination to partnership, from competition to co-operation, from the notion of structure and its parts to the notion of the whole and process. This paradigm rests on the theory of systems with particular interest in the issue of self-organization ${ }^{\mathbf{2 1}}$, and it is tied in with the emergence of new forms of spirituality, supporting the perception of the world in the categories of "the fundamental interconnectedness and interdependence of all phenomena and of embeddedness in the cosmos" 22. Even though the ideas of Capra, similarly to those of Ilya Prigogine and Isabelle Stengers, are frequently grouped with the so called intellectual New Age, and, as such, are viewed by many with skepticism, in reality, since 1996-98 we have been observing a shift from the constructivist and interpretive paradigm to the ecological paradigm ${ }^{\mathbf{2 3}}$. However, I have to stress here that some researchers maintain, as does, for example, Richard McNeil Douglas, that environmentalism "in itself is not a new paradigm, but rather an antithesis [of the modern paradigm of progress - ED], which emerges from the

20 Fritjof Capra, The Web of Life. A New Scientific Understanding of Living Systems (New York: Anchor Books, 1996), 5-13. Cf. also: Thomas A. Arcury et al., "Ecological Worldview and Environmental Knowledge: The 'New Environmental Paradigm'", Journal of Environmental Education, vol. 17 , no. 4 (1986): 35-40.

21 The theory of systems, focused on self-organization, autonomy, integration, and co-operation processes, is attracting a lot of interest. Among the representatives of the systems thinking are two Chilean researchers: Humberto Maturana and Francisco Varela, whose autopoiesis theory describing self-organization of molecular systems is enjoying an interdisciplinary success. It is used in social research by Niklas Luhmann, among others. See: Humberto Maturana and Francisco Varela, Autopoiesis and Cognition: The Realization of the Living (Reidl, London, 1980) and by same authors, The Tree of Knowledge, The Biological Roots of Human Understanding (Boston, MA: Shambhala Publications, 1998). It's worth stressing that Varela, in his neurofenomenology project emphasizes the weight of the Asian traditions (e.g., Buddhism), which introduce themes unknown in the Western tradition into the discourse on experience.

22 Fritjof Capra, David Steindl-Rest, Thomas Matus, Belonging to the Universe: Explorations on the Frontiers of Science and Spirituality (San Francisco: Harper San Francisco, 1991), 70 (part III "The Current Shift of Paradigms").

23 Ewa Domanska, „Die paradigmatische Lücke (paradigmatic gap) in den heutigen Geistesund Sozialwissenschaften", trans. by Michael G. Esc, Historie. Jahrbuch des Zentrums für Historische Forschung Berlin der Polnischen Akademie der Wissenschaften, no. 4 (2010/2011): 34-54.

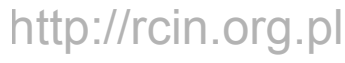


growing contradiction between progress and reality, and only then indicates (...) a need for a new paradigm"24.

It is assumed that the development of ecological humanities began in 1980 with the publication of the book The Death of Nature. Women, Ecology and the Scientific Revolution by Carolyn Merchant. That book, according to Robyn Eckersley, introduced ecology to humanities by showing that the title's death of nature is linked to the departure from animistic and organicistic understanding of nature and the acceptance of the mechanistic idea which serves capitalism by regarding nature as something dead, brought in motion by external forces ${ }^{25}$. However, the real growth of ecological humanities started at the end of the 1990's, which coincided with the dying out of postmodernism as the critical tendencies stimulating the debates, and with the increase of interest in the trends functioning under the banner of various kinds of turns: posthumanist, relational, spatial, postsecular, the turn to materiality (and return to things), the agentive turn, the affective turn, the non-human turn, the species turn, etc. Most definitely the development of ecoposthumanities received a boost from postcolonial studies, the studies of animals and plants, an interest in research ethics, persistent for a considerable length of time, as well as the systems theory (Gregory Bateson, Humberto Maturana, and Francisco Varela) built upon biology and permeating humanities along with complexity theory and cognitive sciences.

In simplifying, we can distinguish the following features of ecological humanities, which in many points reveal the more general dominant trends in present day humanities and social sciences:

1. One of the important features is the merging of humanities and social sciences with life sciences (or, in general, with natural sciences). In this sense, many elements of ecological humanities are tied to the emerging biohumanities and to the integration of sciences, seen more often as the function of their mutually complementary nature rather than as a trans- or inter-disciplinary bond as represented by various "studies"26;

2. Ecological humanities have a critical attitude toward the traditional paradigm based on mechanistic science, on the one hand, and on the other, on patriarchal values (patriarchalism is understood here as

24 Richard McNeil Douglas, "The Ultimate Paradigm Shift. Environmentalism as Antithesis to the Modern Paradigm of Progress", in: Future Ethics. Climate Change and Apocalyptic Imagination, ed. by Stefan Skrimshire (New York-London: Continuum, 2010), 214.

25 Robyn Eckersley, "The Death of Nature and the Birth of Ecological Humanities”, Organization and the Environment, vol. 11, no. 2 (1998), 183. 
masculinistdomination of Man over Nature). In this perspective the world is seen again in the categories of an organism; or, rather, an organic system ${ }^{27}$. This type of humanities is based on the structural metaphor of organicism ${ }^{\mathbf{2 8}}$, which is tied to its characteristic preference for an ontology of connectivity, relational approaches and the so called "flat alternatives", which consider things in their mutual connections and interdependence ${ }^{29}$. In the creation of knowledge within the framework of ecological humanities, we are dealing with the key notions characteristic of organicism, such as: integration, unity, holism, coherence, linkage and inclusion, unions and relations. The researchers, as we could say after Stephen C. Pepper, play the part of "channels of integration"30;

3. It is a remarkable phenomenon that within ecological humanities efforts are made to build a bridge linking Western and Eastern sciences and native knowledges (described further in this article);

4. Ecological humanities dignify the cognitive value of localities (organic attachment thereto) and impose a cross-species perspective. It is within this framework that a multispecies theory of the humanities and social sciences is being created on basis of a the non-anthropocentric approach, critical of the proposition of human exceptionality (the influences of critical post-humanity, but also the attempts of building a new humanity). On this plane there occurs a contact between ecological humanities and posthumanities; ${ }^{31}$

27 Here the issue becomes complicated, since biotechnological progress forces a redefinition of the category of organism. It is no longer understood in opposition to mechanism, as it was in the XVII and XVIII centuries. It is often said that organism is an organic machine (Varela). Charles T. Wolfe, "Do Organisms Have an Ontological Status?" History and Philosophy of the Life Sciences, vol. 32, no. 2-3 (2010), 208.

28 Stephan C. Pepper, World Hypotheses (Berkeley and Los Angeles: University of California Press, 1942). Chapter XI: "Organicism", $280 f f$.

29 Arturo Escobar indicates some characteristics of such approach: "flat versus hierarchical, horizontality versus verticality, self-organization versus structuration, emergence versus transcendence, attention to ontology as opposed to epistemology". Arturo Escobar, "The 'ontological turn' in social theory: a commentary on 'Human geography without scale' by Sallie Marston, John Paul Jones II and Keith Woodward, Transactions of the Institute of British Geographers, vol. 32 (2007), 106. These approaches can be regarded as aspects of the before mentioned theory of complexity.

Pepper, World Hypotheses, 291.

31 Neil Badmington, "Cultural Studies and the Posthumanities", in New Cultural Studies. Adventures in Theory, ed. G. Hall, C. Birchall (Edinburgh: Edinburgh University Press, 2006).

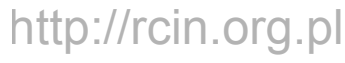


5. This branch of humanities is based on the model of social inclusiveness and often refers to an ethics of solidarity and respect for various forms of life, including those devoid of organic animation (e.g., things). The turn in the interest goes from the individual subject to community;

6. In ecological humanities, the lack or incompleteness of knowledge is considered - as noted by Debora Bird Rose and Libby Robin - not so much an obstacle, as rather the condition of participation in the live system of the planet and the factor of survival ${ }^{32}$.

In the last decade, the growth in popularity of ecological humanities was driven largely by the Australian periodical Australian Humanities Review ${ }^{\mathbf{3 3}}$. Since 2004, Deborah Bird Rose, who has the title of Professor of Social Inclusion, has edited, along with Libby Robin, the Ecological Humanities section in the AHR. In 2006 they published the article "The Ecological Humanities: An Invitation"34, from which one can infer the definition of the version of ecological humanities promoted by the journal, which can be regarded as representative of the concept discussed in this article: ecological humanities constitutes a multidisciplinary domain of research aiming at integration and non-hierarchical treatment of the humanities and natural sciences, Western, Eastern, and native knowledges. Ecological humanities is based on the ontology of connections promoting both the human intercultural relations and interspecies connections. Ecological humanities voices the necessity of submitting to the laws of ecology 35 and regarding humanity as a part of a larger whole of a living system. It would promote an ethics of respect and interspecies solidarity, which is of considerable significance for the

32 Deborah Bird Rose and Libby Robin, "The Ecological Humanities in Action: An Invitation". Australian Humanities Review, no. 31-32 (2004). http://www.australianhumanitiesreview.org/ archive/Issue-April-2004/rose.html [accessed -1.06.2012]. Thus we return to the issue of suspending or deferring knowledge.

33 Theme issues of the journal that attracted wide interest, among them: "Gregory Bateson and Ecological Aesthetics" (vol. 35, 2005); "Ecopoetics and the Ecological Humanities in Australia" (vol. 39-40, 2006); "Writing in the Anthropocene" (vol. 47, 2009); "Unloved Others: Death of the Disregarded in the Time of Extinctions" (vol. 50, 2011).

Deborah Bird Rose, Libby Robin, "The Ecological Humanities in Action”.

35 Barry Commoner in the book The Closing Circle: Nature, Man, and Technology proposed an - as he called it - "informal set of 'laws of ecology" which are as follow: 1. everything is connected to everything else; 2 . everything must go somewhere; 3 . nature knows best; 4 . there is no such thing as a free lunch ("every gain is won at some cost. In a way, this ecological law embodies the previous three laws. Because the global ecosystem is a connected whole, in which nothing can be gained or lost and which is not subject to over-all improvement, anything extracted from it by human effort must be replaced"). Barry Commoner, The Closing Circle: Nature, Man, and Technology (New York: Alfred A. Knopf, 1971), 42. 
consideration of the idea of social justice and opening it up to non-human beings.

In the volume 52 of the AHR magazine for 2012, Deborah Rose and Thom van Dooren published "The Farewell" to the section and announced the emergence from it of a new international interdisciplinary open access periodical called Environmental Humanities ${ }^{\mathbf{3 6}}$. Its editorial board includes Dipesh Chakrabarty, Donna Haraway, Vandana Shiva, Anna Tsing, and Cary Wolfe. The first volume of the periodical was published in November of 2012. In the introductory, program article, we read, that the development of ecological humanities is the answer to the fast changes occurring presently in the environment and, against ecological and social challenges facing the world. The magazine, as the editors declare, is engaging in discussion of fundamental questions about the meaning, the value, the responsibility and the purpose of producing a humanistic knowledge in the context of these changes and challenges ${ }^{37}$.

The editors are pointing towards several characteristics distinguishing their approach from the traditional environmental research developing since the 196o's. And so, first, the discourse held within the framework of the latter has concentrated on the issues of man, the issues of policies and social justice, whereas the new magazine, and the contemporary approach of the ecological humanities, are largely focused on the non-human world and on a critical consideration of the issue of exclusivity of the human species. Secondly, the magazine is supporting the ambition of the environmental humanities of becoming a more scientific domain through a closer cooperation with such disciplines as behavioral economics and cognitive psychology. These fields of knowledge have a particular importance for the research of ecological humanities as the departure from a narrow understanding of causality limited to human (intentional causality), and also they conceptualize in an interesting way the relations between what is human and non-human. Thirdly, the cutting edge of criticism is directed against the mentality born in the womb of the Western-European culture, and, especially against the idea of a passive nature as a resource ready for human use. Fourthly, the journal, and ecological humanities, in general, tend toward building an integrative and complementary biohumanist knowledge combining the humanities and social sciences

36 Home page of „Environmental Humanities" http://environmentalhumanities.org/ [accessed - 3.01.2013]. The editors often use environmental, ecological, sustainable humanities as synonyms.

37 Deborah Rose, Thom van Dooren, Matthew Chrulew, Stuart Cooke, Matthew Kearnes and Emily O'Gorman, "Thinking Through the Environment, Unsettling the Humanities", Environmental Humanities, vol. 1 (2012): 1-5. 
with life sciences. An example of such a research domain is the emerging multispecies ethnography ${ }^{\mathbf{3 8}}$.

The authors published in the AHR often invoke the idea of an Australian ecofeminist, Val Plumwood (1939-2008), who significantly contributed to and influenced the development of the ecological humanities not only in Australia. Her book, Environmental Culture: The Ecological Crisis of Reason (2002) and the article "Nature in the Active Voice" (AHR, vol. 46, 2009) are recognized among the definitive texts for this research domain. Plumwood identified two major tasks of ecological humanities which are "to resituate the human within the environment, and to resituate nonhumans within cultural and ethical domains"39. In dealing with these challenges, the native knowledge(s) will offer help, as they have always viewed the relations of man with nature and the attitude to non-humans (animals, plants, things) in this very way while stressing their strong and close relations and co-dependency.

\section{Traditional Ecological Knowledge and Native Knowledges}

Building a project of ecological humanities is connected with a significant reformulation of understanding of the status and the role of science (and humanities) and its determinants. In the ecological option with its basis in the structuring organicistic metaphor, the progress of knowledge is measured in the degree of its inclusiveness; the more inclusive the knowledge, the more progressive it is; and, in the presently proposed planetary perspective, the better it is, i.e., more open, holistic, integrating, the more "democratic". It is worth noting, that it's not only science that is at stake here. In Western thinking, science is recognized as the most powerful and the most credible source of knowledge; at the same time, with its mechanistic understanding of life processes, linear and progressive conceptualization of change, anthropocentric perception of the relations between man and natural environment, and its acceptance of the individual as the basal social unit, science is increasingly recognized as an anthropocentric myth, which has led to human and ecological catastrophes ${ }^{40}$.

38 S. Eben Kirksey, Stefan Helmriech, "On the Emergence of Multispecies Ethnography", Current Anthropology, vol. 25, no. 4 (2010): 545-576 (theme issue: "On the Emergence of Multispecies Ethnography").

39 Val Plumwood, "Animals and Ecology: Towards a Better Integration", quoted from: Rose, van Dooren (and others), "Thinking Through the Environment", 3.

40 Cf.: Chet Bowers, The Culture of Denial: Why the Environmental Movement Needs a Strategy for Reforming Universities and Public Schools (Albany: State University of New York Press, 1997), 
One of the features of ecological humanities is its criticism of science as the privileged way of cognition. Science is, after all, one of many ways of acquiring and organizing knowledge, and, as it is indicated, not necessarily the best one. These are not new themes. They were present in the discourses of the representatives of the Frankfurt School, as well as the eco-philosophers ${ }^{41}$. Lately this theme has returned with a growing interest in posthumanism and posthumanities.

Recently Ivan Callus and Stefan Herbrechter proposed a useful definition of posthumanism:

Posthumanism (...) may therefore be seen as an attempt to create an interdisciplinary conceptual platform that draws together perspectives and investigations from the arts, the humanities and the sciences in the face of a radical and accelerated questioning of what it means to be human and what the re-imagined end(s) of the human might be. Accordingly, it focuses strongly on the contemporary technological, cultural, social and intellectual challenges to traditional notions of humanity and the institution of the humanities ${ }^{42}$.

Callus and Herbrechter do not mention traditional knowledges as one of the perspectives that might be used to create a platform for a new paradigm to emerge, which, I think, is a major lack in their definition of posthumanism. In the context of typical posthumanist criticism of anthropocentrism, Eurocentrism and cognitive imperialism of Western type of knowledge there is an increased interest in native knowledges. However, indigenous knowledges are recognized not so much as the subject of anthropological research as a platform for building an alternative understanding of the subject, community, the sacred, time, space, relations with non-humans.

It is worth quoting here from a speech of Russell Means (1939-2012) of the Lakota tribal nation, a charismatic leader of North American Indians,

115 and Franz J. Broswimmer, Ecocide. A Short History of the Mass Extinction of Species (London: Pluto Press, 2002).

41 Max Horkheimer, Eclipse of Reason (London: Continuum Press, 2004). With ecophilosophical outlook, Henryk Skolimowski undertook a critique of science in his book Zmierzch światopoglądu naukowego (The Twighlight of Scientific Outlook - Polish edition) (London: Odnowa, 1974) and in his Living Philosophy: Eco-Philosophy as a Tree of Life (Penguin/Arkana, 1992).

42 Ivan Callus, Stefan Herbrechter, "Introduction: Posthumanist subjectivities, or, coming after the subject ...". Subjectivity, vol. 5, no. 3 (2012), 250. 
a well-known activist fighting for human rights, the protection and dissemination of Indian heritage, and for the preservation of the Earth.

Capitalism and communism are simply the opposite sides of the same Eurocentric coin. What the world needs is not a choice between capitalism and communism, between one aspect of euro centrism or eurosupremacism and another. What we need is a genuine alternative to the European tradition as a whole.

This quote constitutes, quite rightly, the motto for the program article by Raymond Pierotti and Daniel Wildcat „Traditional Ecological Knowledge”, in which we read:

What will be gained by placing TEK-based [Traditional Ecological Knowledge] into a broad-based system of knowledge is the ability to access a large amount of information and experience that has been previously ignored, or treated as mysticism. The additional knowledge, with its empirically derived emphasis on the natural world, can provide us with scientifically testable insights into some of the most pressing problems facing humankind today ${ }^{\mathbf{4 3}}$.

It is worth noting here, that the growing popularity of Traditional Ecological Knowledge (TEK here after) is linked to the phenomenon particularly conspicuous in American, as in Australian and Canadian, humanities, which Devon Mihesuah and Angela Wilson called indigenizing the Academy ${ }^{\mathbf{4 4}}$. There is increasingly greater participation of the representatives of native cultures in research work which infuses humanities with traditional knowledge. The shift elasticizes the European "corset of knowledge", especially with regard to the understanding of rationality, subjectivity, the relations between nature and culture, interspecies ties, and the place of humans in the world. Moreover, they begin to study white man in the way in which anthropologists once studied aborigines ${ }^{45}$. This fact might become, I think, of fundamental importance for the future of the humanities.

43 R. Pierotti, D. Wildcat, "Traditional Ecological Knowledge", Ecological Applications, vol. 10, no. 5 (October 2000), 1339.

44 Devon Mihesuah and Angela Wilson, Indigenizing the Academy: Transforming Scholarship and Empowering Scholarship (Lincoln: University of Nebraska Press, 2004).

45 Cf.: Orin Starn, "Here Come the Anthros (Again): The Strange Marriage of Anthropology and Native America". Cultural Anthropology, vol. 26, no. 2 (2011), $195 \mathrm{ff}$. 
TEK assumes a critical approach to the Western tradition, criticizing everything that Europeans regard as great achievements of Western science, considering it the cause of human and natural catastrophes. Instead, it returns to native traditions stressing common interdependence among the components of the world existing in the world or in the cosmos, and especially, the definition of humans as part of an ecosystem and with the relations of human to non-human persons based on kinship. (Hence the interest in "new animism" and "new totemism", which stress that people come from non-human organisms and that the plant-person or animal-person had existed before the human person, and, for that reason, in particular, are placed higher in the hierarchy of beings ${ }^{46}$ ). In this conceptualization, nature is home, and not an objectivized and ready to be used natural resource. Relations to nature and non-humans are focused on local places (hence interest in space, locality, epistemic places, which do not just contain, but also condition the achievement of knowledge) and rest on reciprocity and mutual respect. TEK is focused on co-operation, symbiotic coexistence, rather than competitiveness, and imparts the attribute of causality and autonomy to non-human beings in relation to people. Various indigenous sciences, partly through questioning the difference between metaphysics and science, make understanding of science more adaptable. They include Western science within their framework, but they also transcend it insofar as it lacks proper tools to consider the issues of an affective and intuitive essence of the world, so important to indigenous knowledges. Characteristic of this knowledge is the conviction, that human existence remains in a close, intimate relation with the environment and with other living beings, which is based on kinship. An important characteristic of this knowledge is the conviction that the Earth possesses causality and vital energy. Similarly to other trends in the humanities today, indigenous sciences recognize that their goal is to subordinate nature to humans, but with a respectful approach and responsibility for mutual fate ${ }^{47}$. The ecology promoted by TEK has therefore a kincentric nature, i.e., at its center lies the idea of kinship, strong ties, interdependencies, and the integration of vital processes, both physical and spiritual ${ }^{48}$.

The aforementioned Pierotti and Wildcat declare:

46 Graham Harvey, Animism. Respecting the Living World (New York: Columbia University Press, 2006). See also: Philippe Descola, "Human Natures", Social Anthropology/Anthropologie Sociale, vol. 17, no. 2 (2009): 145-157.

47 Cf.: Robert W. Preucel, "Indigenous Archaeology and the Science Question", Archaeological Review from Cambridge, vol. 27, no. 1 (2012), 131.

48 Cf.: Enrique Salmon, „Kincentric Ecology: Indigenous Perceptions of the Human Nature Relationship". Ecological Applications, vol. 10, no. 5 (2000), 1328. 
We consider TEK to be an intellectual foundation for an indigenous theory and practice of politics and ethics, centered on natural places and connection to the natural world, which is capable of generating a conservation ethic on the part of those who follow its principles. TEK is based upon empirical observations resulting from patient observation of the natural world and its patterns. TEK is inherently multidisciplinary because it links the human and the nonhuman, and is not only the basis for indigenous concepts of nature but also for concepts of politics and ethics. There are therefore no clearly defined boundaries between philosophy, history, sociology, biology, and anthropology in indigenous thought ${ }^{49}$.

Further on, the authors stress, TEK is opposed to romantic notions of the noble savage and the idea of closeness with nature, ideas fabricated by Western philosophy and later on used by those interested in environmental protection (a program undertaken in the interest of humans). TEK emphasizes that both nature and nonhuman beings have their own reasons for existence, which are totally independent of human ends and this independence must be respected. It is worth mentioning that TEK is based on experience (experience of the place); that it re-evaluates the ideas of politics and ethics, in which it includes nonhuman beings as independent subjects; it advances a new understanding of personalism whereby personality is attributed to various nonhuman beings, e.g., plant person, rock person ${ }^{50}$. It should also be noted that in the definition proposed by the researchers coming from native communities, traditional knowledge is not static but dynamic and subject to change. Moreover, the fundamental difference between TEK and aboriginal knowledge is often stressed, whereby the definition of aboriginal is used in opposition to globalized culture and is considered synonymous with traditional knowledge.TEK is more focused on the ecological aspects of traditional (aboriginal) knowledge and is tied to the conviction, that local ecological problems can't be solved without TEK. At stake here is the building of a comprehensive knowledge of sustainable growth and the issue of managing natural resources based on the needs and expectations of a community (community based management). It includes promoting the so called adaptive management, which reveals the practical aspect of TEK, resting on the conviction that nature cannot be controlled nor can its development be forecast. Hence, it is necessary to fit into

49 Pierotti, Wildcat, "Traditional Ecological Knowledge", 1335.

50 Graham Harvey maintains that the new animism is the kind of personalism. Cf.: Harvey, Animism, $22 \mathrm{ff}$. 
the natural cycles of regeneration and to harmonize the human use of the environment with these cycles ${ }^{51}$.

This raises the issue of the degree to which TEK and native knowledge can be compatible with Western science and "if and how the university can be a place for a different knowing - different epistemologies, different knowledge"52. Within posthumanism and relational ontologies they are often treated as equal. Articles are written, coauthored by scientists and natives. These interesting experiments bring forward the ways of obtaining knowledge and its aspects displaced by Western science, which refers to a specific rationality. Among such experiments is one dealing with the relation between intuitive knowledge based on practice and a science based on the methods of controlled observation, experiments and logical argumentation ${ }^{\mathbf{5 3}}$. It is a significant feature of TEK that it starts with practice and rests on experience. It is possible that this very knowledge constitutes the needed model of knowledge that is of an interdisciplinary nature, inclusive, connecting the spiritual with the material, is based on co-substantial kinship, shared heritage and ancestry, and it is governed by a principle of relatedness and ethics of respect for all living things. What is more, indigenous knowledges have strong survival value, in fact these are "knowledges about how to survive" 54.

51 Roy C. Dudgeon and Fikret Berkes, "Local Understanding of the Land: Traditional Ecological Knowledge and Indigenous Knowledge", in: Nature Across Cultures: Views of Nature and the Environment in Non-Western Cultures, ed. by H. Selin (Kluwer Academic Publishers, 2003), 85. Cf: Gregory Cajete, Native Science: Natural Laws of Interdependence (Santa Fe, New Mexico: Clear Light Publishers, 2000).

52 "Different Knowings and the Indigenous Humanities". Daniel Coleman in Conversation with Marie Battiste, Sákéj Henderson, Isobel M. Findlay, and Len Findlay, ECS: English Studies in Canada, vol. 38, no. 1 (2012), 142.

53 Annette Wilson and Orville H. Huntington, "They're here - I can feel them: the epistemic spaces of Indigenous and Western Knowledges", Social and Cultural Geography, vol. 9, no. 3 (2008), $264 \mathrm{ff}$.

54 "Different Knowings and the Indigenous Humanities", 145, 157. Marie Battiste who for years work on the indigenous knowledges and their relations with academia, claims, that: "But indigenous knowledge and bringing it to the indigenous humanities is another way for us to be able really to expose Eurocentric knowledge systems as being dismissive, as being appropriative, as diminishing others in multiple ways. And it's a way for us to talk back to them, to create an awareness of that and to recognize that that awareness of the philosophical traditions upon which they depend, Socrates and all those people, really is not talking to the generation of today, of people who are living in a particular place in a particular environment, trying to survive with the water they have, trying to survive on the land they have. And those are the kinds of survival issues that have always been part of indigenous peoples' living in place and how so much more can be learned from indigenous people about how to do that sustainably and do that in such a way that relationships with each other become the foundation of 
I would claim that in this context, archaeology has the capacity to serve as a bridging discipline and can play an important role in a cross-epistemological dialogue and in the process of connecting and integrating Western type of humanities and social sciences as well as life sciences ${ }^{55}$ with indigenous knowledges (and ways of knowing). While dealing with the problem of heritage and contemporary pasts and variously understood sacred, archaeology already became a site for decolonization of the mind (to use Ngugi wa Thiong'o's phrase) and a liberating knowledge. I would even say that archaeology will be an indigenous archaeology or not be at all (as an important field of knowledge within inclusive and holistic body of knowledges of the past). However, I would like to stress, that in this paper, indigenous are various native beings living on the Earth (being earth-born) (only some of them are human) thay are connected through certain kinship based on a co-substance of carbon life (carbon based life forms). By contrast non-natives that they live elsewhere and their life, as astrobiologists would say, is not carbon based ${ }^{56}$.

In this context, I would propose thinking about indigenous archaeology (I am aware that there are many different indigenous archaeologies and various definitions of this field), as a platform to rethink what future oriented archaeology understood as a particular knowledge of the past might be. Thus, indigenous archaeology will not be an archaeology "with, for and by" Indigenous people, but rather a "multispecies community archaeology" oriented toward the future of (multispecies) collectives and carbon based forms of life.

Let's imagine that the below definition of indigenous archaeology serves as a reference point for thinking about archaeology in general. Indigenous archaeology is:

an expression of archaeological theory and practice in which the discipline intersects with Indigenous values, knowledge, practices, ethics, and

a culture, rather than the economy, making money and having the almighty dollar decide how we do things, and so on. So there's a very different kind of humanity that emerges from our contrasting a Eurocentric humanity with an indigenous humanity to really say we could learn so much more". Ibid, 157-158.

55 Archaeology is already seen as a bridging discipline between social sciences and natural sciences: Danika Parikh and Katie Hall, introduction to a theme issue entitled "Science and the Material Record" of the Archaeological Review from Cambridge, vol. 27, no. 1 (2012), 3.

56 So, I am applying here not a global perspective, but a planetary one. I want to stress, that by universalization of a term "indigenous", I am not intending to de-politicize past and current issues related to fights of indigenous communities for their land, rights and ancestors, but I am proposing a future oriented vision of how our knowledge about the past might look like. 
sensibilities, through collaborative and community-originated or - directed projects, and related critical perspectives ${ }^{57}$.

As such, indigenous archaeology is not only a critical discourse and a decolonizing discipline but also a space of cross-epistemological research and advocacy of alternative ways of thinking about heritage, relations between humans and non-humans, materiality, environment, agency, indigeneity; the sacred (and sacred places), tradition, etc.

In fact, indigenous knowledges and ways of knowing form probably the most interesting but difficult challenge to the humanities and social sciences. I think, that if academia wants to be inclusive it will indeed change dramatically our presuppositions of knowledge building, authorship and verification of knowledge. Surprisingly however, there are - it seems to me - few real problems with relations between indigenous knowledges and life sciences. Thus, the latest discoveries in the field of neuroscience confirm certain indigenous ideas about plants. So for example plant neurobiology allows challenges a traditional view of plants as passive and insensitive. Matthew Hall, in his book Plants as Persons. A Philosophical Botany (2011), writes that

plants and humans share a basic, ontological reality as perceptive, aware, autonomous, self-governed, and intelligent beings. Like other living beings, plants actively live and seek to flourish. They are self organized and self created as a result of interactions with their environment. (...) With guidance from animistic cultures and the evidence from contemporary plant sciences, the latter stages of this study argues for recognizing plants as subjects deserving of respect as other-than-human persons ${ }^{58}$.

Ecological humanities fits in and is part of discernible reconfigurations in the theory of social sciences and humanities which show through, e.g., the replacement of the vertical model of knowledge with the horizontal model, in which the importance of flat ontologies and relational approaches increases substantially ${ }^{59}$. It can be stated that the contemporary humanities and social

57 George P. Nicholas, "Native Peoples and Archaeology", in Encyclopedia of Archaeology, vol. 3, ed. by Deborah M. Pearsall, (Oxford: Elsevier 2008), 1660.

58 Matthew Hall, Plants as Persons. A Philosophical Botany (Albany, NY: Sunny Press, 2011), 12-13.

59 Such relational approaches (and flat ontologies) are exemplified by Bruno Latour's actor-network- theory and the new social theory by Manuel DeLandy (assemblage theory), and recently also by the relational archeology project by lan Hodder. Harvey also includes the new animism into the category of relational epistemology. See: Bruno Latour, Reassembling the Social; Manuel DeLanda, A New Philosophy of Society. Assemblage Theory and Social Complex-

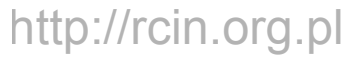


sciences focus on the issues of interrelations. Among many factors forcing this refocussing, the most interesting is the conviction, that "everything connects to everything else", shared both by the traditional ecological knowledges, and by quantum physics, to which, by the way, we owe the notion of entanglement, extremely popular in today's humanities, as well as in biology. It's worth invoking here the principle of organicism, which states that: „it is such a system that an alteration or removal of any element would alter every other element or even destroy the whole system"60. However, as the above quoted Pierotti and Wildcat state, we should stress here with all force, that "it is not simply a homily or a romanticized cliché, but instead, a realization that no single organism can exist without the web of other life forms that surround it and make its existence possible"61. In the context of such reasoning, a pyramidal metaphor of a vision of reality has given way to the metaphor of convoluted relations, networks, assemblages, collectives, kinships, societies, and communities. The issue of the subject and the object become secondary to the problem of relations among them, connections and dependencies (relationalism), and the idea that things themselves became relational.

It might seem that ecology, which constituted itself in the 19th century as a subdiscipline of biology, presently plays the same role as did cultural anthropology in the time of domination of the postmodernistic trends, i.e., it prescribes the fields and the subjects of research for humanities and offers analytical categories, as well as the understanding of culture. I think, though, that we are not only dealing with an "ecologizing of the humanities". The research conducted about contemporary humanities and social sciences ${ }^{\mathbf{2}}$ allows the

ity (London: Continuum, 2006); lan Hodder, Entangled. An Archaeology of the Relationships Between Humans and Things (Malden, MA: Willey-Blackwell, 2012); Harvey, Animism, 21.

60 Pepper, World Hypotheses, 300.

61 Pierotti, Wildcat, "Traditional Ecological Knowledge", 1336. It is worth recalling the words of Thomas Kuhn: "the reception of a new paradigm often necessitates a redefinition of the corresponding science. Some old problems may be relegated to another science or declared entirely "unscientific". Others that were previously nonexistent or trivial may, with a new paradigm, become the very archetypes of significant scientific achievement. (...) The normalscientific tradition that emerges from a scientific revolution is not only incompatible but often actually incommensurable with that which has gone before". Thomas S. Kuhn, The Structure of Scientific Revolutions (Chicago: The University of Chicago, 1970, [International Encyclopedia of Unified Science, vol. 2, no. 2]), 103.

62 See: my article: "Wiedza o przeszłości - perspektywy na przyszłość" (Knowledge of the Past - Prospects for the Future, in Polish), Kwartalnik Historyczny, vol. CXX, no. 2 (2013): 221-274. In this text I presented the results showing the condition of today's humanities and social sciences based on the query, which included about 1200 issues of 300 journals representing various disciplines of humanities and social sciences, published in 2010-2012. 
assumption that the phenomena described here, although currently characteristic of just avant-garde trends and approaches, might be a portent of not just the further shifts but of an upheaval. I am not alone with my hypothesis that we are on the threshold of a real revolution stimulated by processes occurring in the world (connected with climate change and with the degradation of the environment, as well as the cultural-political changes). These processes enhance the transformations occurring in academe, but they mostly stimulate discoveries within biological sciences, especially in molecular biology, cognitivism, and neurosciences ${ }^{\mathbf{6 3}}$.

\section{Biohumanist Background of Ecological Humanities}

The dreams of many researchers about producing knowledge connecting the humanities with life sciences ${ }^{64}$ and the knowledge that can be defined as biohumanities ${ }^{65}$ are advanced into reality. This field of study and its critical edges are determined, on the one hand, by neuroscience, and on the other, by traditional knowledges, introduced particularly into American, Australian and Canadian academies by the researchers representing native cultures.

63 Doris Bachmann-Medick also reaches this conclusion while considering contemporary research turns in humanities. She sees revolutionary symptoms on the scale of the Copernican revolution in the neurobiological turn. Doris Bachmann-Medick, Cultural Turns. New Orientations in the Study of Culture, trans. by Adam Blauhut (Berlin/Boston: De Gruyter, 2016).

64 It is worth noting here the C.P. Snow's idea of the late 1950 s about 'two cultures', i.e. the humanities and sciences, which cannot find mutual language. C.P. Snow, Two Cultures (London: Cambridge University Press, 1959); Edward O. Wilson appealed for unity of the two cultures in his book of the late 1990s: Consilience: The Unity of Knowledge (New York: 1998).

65 The term "biohumanities" is used by Karol Stotz and Paul E. Griffiths in the article "Biohumanities: Rethinking the Relationship Between Bioscience, Philosophy, and History of Science, and Society", The Quarterly of Biology, vol. 83, no. 1 (2008): 37-45. The authors define it as "the perspective on the relations between humanities (especially philosophy and history of science), biology and the society. In this option, the humanities do not only interpret the significance and influence of biological knowledge, but also contributes to our understanding of biology itself" (p. 37). Thus biohumanities of Stotz and Griffith represents a constructive critique of science, which uses humanities to understand biology. In my considerations, while using the term biohumanities, I propose a different approach to this research perspective. My argument is about an incomplete understanding of the phenomena that are important to contemporary knowledge offered partially by the humanities, and in part, by sciences (the issues of identity, thoughts on the differences and relations between species, biopolitics, research of the environment, space, time, etc.) and I advocate the complementary nature of these two domains. The future educational perspective assumes studies (masters and doctoral) combining humanities and sciences. Examples of new biohumanistic disciplines include neuroesthetics, neuronal history of art, neuroanthropology, and neurotheology, which require studies of art history, anthropology, theology, as well as cognitivism. 
These "explosive mixtures" give rise to various avant-garde approaches, which can be defined as multispecies theory of the humanities and social sciences.

The discoveries of neurosciences, as well as the progress in brain research (there is talk about "neuroscientific turn" and proclamation of the advent of the "neurocentric era"66), as well as zoological research (especially primatology) and botanical research (neurology of plants), in a significant way contribute to the questioning of the traditional idea of human nature and relations between humans and nonhuman animals, and plants. On the other hand, molecular biology, which deals with the influence of molecular properties (especially proteins and nucleic acids) on the functioning of living organisms, encourages a molecular level approach when talking about (bio-cultural) subjectivity and identity.

The discoveries made through research on the human microbiome, cocreated by fungi, bacteria, viruses, living in the organism, allow us to see the human body in the categories of a specific ecosystem, and to see the human as a congregation of human and nonhuman elements. This is essential for today's redefinition of the understanding of humans and their place in the world, their bodies and their lives ${ }^{67}$. As the authors of the manifesto "Anthropology of Microbes" maintain, "Studies of the human microbiome are helping us to evolve our sense of personal identity. We are seeing ourselves with increasing definition as a 'supraorganism' composed of microbial and human cells, as well as human and microbial genes, with the number of microbial components vastly exceeding the number of human (Homo sapiens) components"68. In the similar vein, the authors of an article "A Symbiotic View of Life: We Have Never Been Individuals" claim that:

All classical conceptions of [biological] individuality are called into question by evidence of all-pervading symbiosis. (...) Estimates that $90 \%$ of the cells that comprise our bodies are bacterial (...) belie any simple anatomical understanding of individual identity. (...) Neither humans, nor

66 The Neuroscientific Turn. Transdisciplinarity in the Age of the Brain, ed. by Melissa M. Littlefield and Jenell M. Johnson (Ann Arbor: The University of Michigan Press, 2012); Peter Becker, "The Coming of a Neurocentric Age?" Medicina \& Storia, vol. X, no. 19-20 (2010): 101-128 and Jake F. Dunagan, "Politics for the Neurocentric Age”, Journal of Futures Studies, vol. 15, no. 2 (2010): 51-70. See also: Ruth Denkhausa and Mathias Bös, "How Cultural is 'Cultural Neuroscience'? Some Comments on an Emerging Research Paradigm", BioSocieties, vol. 7, no. 4 (2012): 433-458.

67 Peter J. Turnbaugh, Ruth E. Ley, Micah Hamady, Claire M. Fraser-Liggett, Rob Knight \& Jeffrey I. Gordon, "The Human Microbiome Project", Nature, no. 449, (18 October 2007): 804-810.

68 Amber Benezra, Joseph DeStefano, and Jeffrey I. Gordon, "Anthropology of Microbes", Proceedings of the National Academy of Sciences, vol. 109, no. 17, (24 April 2012), 6378. 
any other organism, can be regarded as individuals by anatomical criteria. To capture this complexity, the term "holobiont" has been introduced as the anatomical term that describes the integrated organism comprised of both host elements and persistent populations of symbionts (...). [O] rganisms are anatomically, physiologically, developmentally, genetically, and immunologically multigenomic and multispecies complexes. Can it be that organisms are selected as multigenomic associations? Is the fittest in life's struggle the multispecies group, and not an individual of a single species in that group? (...) As Lewis Thomas (...) commented when considering self and symbiosis: "This is, when you think about it, really amazing. The whole dear notion of one's own Self-marvelous, old free-willed, free-enterprising, autonomous, independent, isolated island of a Self-is a myth" 69 .

It is at this molecular level that it becomes clear, that the human animal is a multispecies hybrid, a metacommunity being undergoing continuous process of symbiotic becoming and co-evolution. The level of bio-micro-neuro discourse shows that people, plants, and animals are not as essentially different as the humanities-cultural discourse would wish to show (and wants to prove). Donna Haraway says, paraphrasing Bruno Latour, that "we have never been human"70 and - as the biologists mentioned above claim - we have never been individuals, in the way that the anthropocentric perspective and species chauvinism would have it.

In this context, research on plants is particularly interesting. Plants, as scholars of the rapidly developing neurobiology of plants claim, can choose among different ways of behavior, respond to stress, e.g., the lack of water), and even feel desynchronosis (jet lag), are able to distinguish between themselves and others, are autonomous beings (let us note that the notion of autonomous has been used solely in relation to man), and their life has intrinsic value $^{71}$. The interest in plants furthered through various biohumanities projects has resulted in the emergence of a subdiscipline defined as sociology

69 Scott F. Gilbert, Jan Sapp and Alfred I. Tauber, "A Symbiotic View of Life: We Have Never Been Individuals", The Quarterly Review of Biology, vol. 87, no. 4 (2012), 327, 331, 334.

70 See: Nicholas Gane, „When We Have Never Been Human, What Is to Be Done?: Interview with Donna Haraway", Theory, Culture \& Society, vol. 23, no. 7-8 (2006): 135-158. "We Have Never Been Human" which is also the title of part I of Haraway's book, When Species Meet (Minneapolis: University of Minnesota Press, 2008).

71 Federal Ethics Committee on Non-Human Biotechnology [ECNH], The Dignity of Living Beings with Regard to Plants. Moral Considerations of Plants for Their Own Sake, 2008. Cf. also: Hall, Plants as Persons. 
of mushrooms $\mathbf{7 2}^{\mathbf{2}}$, which inspires researchers trying to consider the principles of social co-existence by researching the principles of the functioning of mycelium.

In stimulating changes occurring in the humanities, an important role has been played by the discoveries in the field of synthetic biology. This domain, having risen as the result of the integration of biological sciences (chiefly molecular biology) with engineering and mathematics, and seen as the future of biotechnologies, has opened up possibilities of creating new forms of life and modifying the existing ones. The publishing, in 2001, of the outline of human genome and a rapid development of synthetic biology in recent years, offers increased possibilities of manipulating DNA. In 2010, an American geneticist, Craig Venter, who had previously decoded the human genome, created the first synthetic bacterium, given the name Synthia. The creation of a self-dividing cell is considered a breakthrough in genetic engineering and an opening of the way to the creation of an artificial life, and the subsequent related discoveries cause revolutionary changes not only in medicine, but also in manufacturing. They also change the humanities, positing a redefinition of the understanding of life. This issue, however, cannot be raised only within the humanities, hence the necessity of complementary approaches in union with life sciences ${ }^{73}$.

\section{Conclusion}

In the humanities of the late 1990s, there occurs the process, defined by Andrew Pickering, a sociologist of science, as "the posthumanist displacement of our interpretative frameworks" 74 . It can be said that this process reveals the emergence of diversified trends or approaches sometimes described as non- or post-anthropocentric or post-European humanities, and, sometimes, as posthumanities, ecological and/or environmental humanities. However,

72 Anna Tsing, "Arts of Inclusion, or How to Love a Mushroom", Manoa. A Pacific /ournal of International Writing, vol. 22, no. 2 (2010): 191-203.

73 The magazine Environmental Values, vol. 21, no. 1 (2012) devoted its special issue to synthetic biology, described there as a form of radical life engineering (as distinguished from genetic engineering). „The final goal - says Marianne Schark in her article "Synthetic Biology and the Distinction between Organisms and Machines" - is not to begin with the naturally occurring organisms and changing them, but a specialized assemblage of (micro-) organisms from the functional biological parts" (p. 20). This procedure raises an ethical dilemma regarding the status of organisms thus created ("living machines"), and it complicates the understanding of relations between the artificial and the natural.

74 Andrew Pickering, "The Mangle of Practice: Agency and Emergence in the Sociology of Science", The American Journal of Sociology, vol. 99, no. 3 (1999), 561. 
in my opinion, we are no longer talking about further turns or avant-garde trends, about the redundancy of notions and names with the suffix post in anticipation of the future (post-human, post-secular, post-European, postwhite, post-gender, etc.), but about a slow change in consciousness, noticed by many in recent years, a change in the way the world is perceived, and related attempts, observed in academe, of putting forward a different theory of knowledge and creating a new meta-language. Such knowledge is transformational, emancipating, and visionary.

Today's humanities are a part of the process of building holistic, inclusive, integrating, and complementary knowledges that would combine humanities and natural sciences, and would include indigenous ways of knowing into its framework. Moreover, the most radical idea, however, is that the human is not its only author ${ }^{75}$. The choice of ecological humanities as the preferred research perspective and interpretative framework is therefore the choice of a world-view connected with its background project of social transformation from industrial to ecological society. It is also an educational idea aiming at educating anyone sensitive to ecology and other forms of existence.

Where are today's humanities headed? They are headed for local, realistic utopias. Among the indications of this direction are the increasingly popular ecological humanities, feeding on the ideas of symbiotic relations based on mutually dependent human communities and non-human personae. These are the utopias in which the explanation of the historical process by means of theories of conflict is replaced with theories of cooperation, coexistence, and collaboration, and the hitherto ubiquitous notion of trauma as the basis of shaping the individual and communal identity is replaced by the notion of empathy and the subject capable of adaptation, revitalization, and

75 I refer to the research of primatologists and to texts published in scientific periodicals and coauthored by chimpanzees (specifically bonobo, the so called pygmy chimpanzee (Pan paniscus). See: Sue Savage-Rumbaugh, Kanzi Wamba, Panbanisha Wamba, and Nyota Wamba, "Welfere of Apes in Captive Environments: Comments On, and By, a Specific Group of Apes". Journal of Applied Animal Welfare Science, vol. 10, no. 1 (2007): 7-19. Obviously, the apes (Kanzi Wamba, Panbanisha Wamba, and Nyota Wamba) did not write the article, but they communicated with the researcher (Sue Savage-Rumbaugh) and responded to questions about their needs. The article attracted considerable interest, as it questions human exclusivity as cognitive authority and it shows possibilities in multi-species authorship and in building a transspecies knowledge. (It should be noted that such coauthorship related not only to animal, but also intelligent machines). G.A.Bradshaw shows a radical approach when she maintains that "wildlife conservation must be transformed from the species conservation project to the project for social justice and auto determination, whereby epistemic authority decision making is not only shared with the other species, but it is also dictated by non-human species". Gay A. Bradshaw, "An Ape Among Many: Co-Authorship and Trans-species Epistemic Authority", Configurations, vol. 18 (2011), 28. 
autoregeneration. Maturity in the human being is measured in the degree of adaptation and empathy: the more empathetic a human being is toward others, both humans and non-humans (capable of building neuronal connections?), the higher the degree of maturity. In this option, to be a person worthily representing human species is to be homo empathicus ${ }^{76}$.

\section{Translation: Bożena Gilewska}

76 It is about neuronal understanding of empathy. Due to the discovery of mirror neurons, called by Daniel Goleman "the neurons that connect people”, it is acquiring a special bridge status in humanities and neuroscience (i.e., in the emerging biohumanities). As a species, according to researchers, we are neurobiologically programmed to create ties, it is important, however, that these neurons be properly activated, which is the essential role of rearing and education. Roy Mukamel, Arne D. Ekstrom, Jonas, Kaplan, Marco lacoboni, and Itzhac Fried, "SingleNeuron Responses in Humans During Execution and Observation of Actions", Current Biology, vol. 20, no. 8 (2010): 750-756. Cf. also: Jeremy Rifkin, The Empathic Civilization. The Race to Global Consciousness in a World of Crisis (New York: Penguin, 2009), gff.

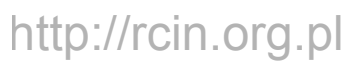

